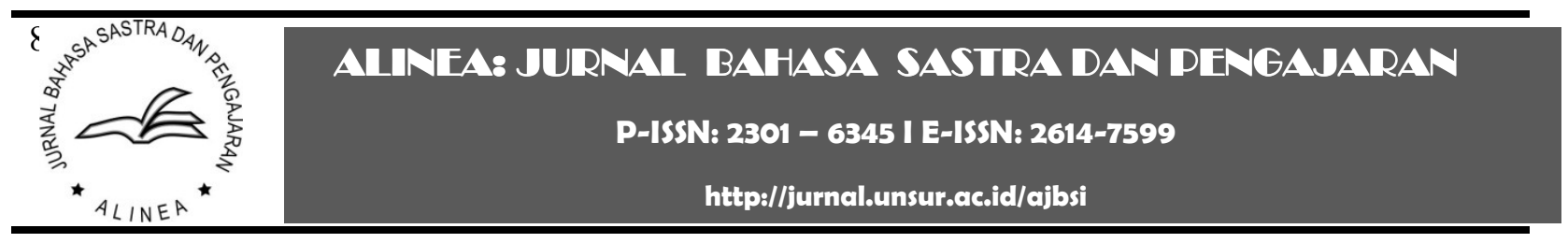

\title{
TINGKAT KETERBACAAN TEKS KESEHATAN DALAM WEBSITE RESMI WHO PADA MASA PANDEMI COVID-19
}

\author{
Yessy Purnamasari \\ Politeknik Negeri Bandung, Indonesia
}

Riwayat artikel:

Dikirim: 11 Juli 2021

Direvisi: 17 Juli 2021

Diterima: 17 Jul 2021

Diterbitkan: 31 Oktober 2021

\section{Katakunci:}

COVID-19, tingkat keterbacaan, teks kesehatan, SFL

Keywords:

COVID-19, readability, health articles, SFL

Alamat surat

yessy.purnamasari@polban.ac.id

\begin{abstract}
Abstrak:
Artikel ini akan membahas keterbacaan teks-teks kesehatan yang dirilis oleh WHO yang berkaitan erat dengan pandemi Covid-19. Melalui metode deskriptif kualitatif, formula Gunning Fog Index digunakan untuk menentukan tingkat keterbacaan melalui prosedur pencocokkan hasil perolehan nilai Fog Index dengan tabel Estimated Reading Grades berdasarkan teori Heydari. Sumber data penelitian berupa empat artikel berbahasa Inggris. Analisis data mengggunakan teori Grammatical Intricacy (GI) dan Lexical Density (LD) yang menitikberatkan pada kerumitan tata bahasa serta kepadatan diksi melalui pemanfaatan text analyzer. Berdasarkan hasil analisis, tingkat keterbacaan teks kesehatan pada website resmi WHO di masa pandemi COVID-19 dikategorikan sebagai teks dengan kesulitan cukup tinggi untuk dipahami dengan skor LD rata-rata 52,55\% dan skor rata-rata Fog Index mencapai 12,55. Target pembaca untuk teks ini disarankan adalah masyarakat dengan minimal pendidikan sekolah menengah ke atas agar teks dapat dipahami dengan tepat.
\end{abstract}

\begin{abstract}
:
This article will discuss the readability of health articles published by WHO on which relates to the current COVID-19. Through the qualitative descriptive methodology, the Gunning Fog Index formula is used to determine the readability through the procedure of matching the Fog index results with the Heydari's theory on Estimated Reading Grades. This research takes four main articles written in English as the data. Data analysis by using the theory of Grammatical Intricacy and Lexical Density using text analyzer website. The results show that the health articles published by WHO during the pandemic are difficult to read by the targeted readers as the average LD score shows $52,55 \%$ and the average Fog Index score is 12,55. The targeted readers for these texts are those with minimum high school educational background to ensure that the content of the text are correctly understood.
\end{abstract}

\section{PENDAHULUAN}

Media massa merupakan salah satu alat penyebaran informasi yang keberadaan dan bentuknya berevolusi dari waktu ke waktu. Media cetak yang dulu mendominasi dalam bentuk koran, majalah, maupun tabloid, saat ini harus mengalah pada kejayaan media online yang mampu menjangkau seluruh sudut peradaban dengan internet sebagai teknologi pendukungnya. Seiring dengan hadirnya revolusi industri 4.0 yang diinisiasi pada tahun 2018, penggabungan teknologi otomatisasi dalam pertukaran data yang menghasilkan konektivitas antara manusia, mesin, dan data dikenal dengan Internet of Things (IoT) (Hidayat). Kehadiran IoT yang mulai menggeser dominasi tangan manusia dalam segala hal juga menuntut adanya literasi media dan teknologi sehingga peradaban manusia tidak terhapus oleh otomatisasi industri. Dalam perjalananannya, salah 
satu media online yang kini dimanfaatkan dalam institusi resmi sebagai media informasi adalah penggunaan website.

Penggunaan website sebagai wadah resmi berbagi informasi merupakan inovasi dalam menjawab tuntutan revolusi industri 4.0 yang menekankan model digital dalam seluruh aspek kehidupan. Website diyakini mampu menjadi media penghubung antara institusi dengan masyarakat sebagai pengguna karena karakteristiknya yang aktual, update, interaktif, dan personal (Apriananta and Wijaya). Sebagai contoh, pemanfaatan website sebagai media promosi hasil pertanian dan peternakan masyarakat merupakan langkah solutif untuk menjembatani proses distribusi sumber daya alam melimpah di suatu daerah ke daerah lainnya karena website dirasa mampu meningkatkan jangkauan pasar (Muharam and Persada). Selain sebagai sarana komunikasi, website juga banyak digunakan sebagai media promosi karena sifatnya yang mudah dikostumisasi sesuai kebutuhan pengguna (Anjarkusuma et al.). Berdasarkan karakteristik dan sifatnya yang fleksibel, tidak heran apabila website banyak digunakan di berbagai institusi sebaga media komunikasi resmi.

World Health Organization atau WHO merupakan salah satu institusi resmi dunia yang turut menggunakan website sebagai media informasi dan komunikasi. Melalui laman www.who.int, WHO tidak hanya menginformasikan isu dan berita terkini terkait dunia kesehatan, tetapi juga turut mengkampanyekan pendekatan intersektoral dalam bidang kesehatan. Sebagai rujukan nomor satu dunia terkait kesehatan, WHO memegang peranan penting sebagai sumber terpercaya, terutama dalam masa pandemi Covid-19. Berbagai informasi terkini terkait jumlah kasus, penanganan, hingga data statistik, semua tersaji rapi dalam website resminya. Dalam penulisannya, berbagai artikel yang dimuat di website resmi $W H O$ dapat diakses dengan menggunakan 6 bahasa resmi dunia yaitu Bahasa Inggris, Arab, Mandarin, Prancis, Rusia, dan Spanyol.

Sebagai media informasi, sudah selayaknya artikel yang dipublikasikan dalam website resmi WHO dapat dipahami dengan mudah oleh berbagai level pembaca. Melalui analisa tingkat keterbacaan teks, penelitian dilakukan dengan tujuan untuk mengidentifikasi tingkat keterbacaan dari lima teks kesehatan yang berkaitan dengan pandemi Covid19. Artikel terpilih yang dianalisis mencakup latar belakang penyebaran virus, langkah pencegahan, penjelasan gejala, sarana informasi terkait perlindungan diri, dan seputar mitos mengenai virus yang berkembang di masyarakat. Pemilihan kelima teks didasarkan pada penempatan artikel yang menjadi tajuk utama di bagian Newsroom mengenai pandemi Covid-19. Dengan demikian, melalui penelitian diharapkan dapat diketahui tingkat keterbacaan teks kesehatan yang dipublikasikan oleh WHO. Teks dianalisis dari sisi kerumitan Bahasa (Grammatical Intricacy/ GI) dan kepadatan leksikal (Lexical Density/LD). Dari sisi urgensi penelitian, dengan mengetahui tingkat keterbacaan teks tersebut, target pembaca yang mampu memahami konten dari teks tersebut dapat dipetakan dengan baik sehingga informasi yang terkandung di dalamnya dapat terserap dengan baik.

Istilah, "keterbacaan" dalam bahasa Inggris disebut readibility. Konsep keterbacaan menurut Dale dan Jeanne Chall dalam (DuBay) dijelaskan bahwa seluruh unsur yang terdapat di dalam teks (termasuk interaksi antarteks) memiliki pengaruh terhadap keberhasilan pembaca dalam memahami isi bacaan dengan kecepatan membaca yang optimal. Gililand dalam (Suherli) menyatakan ada tiga faktor yang terkait dengan keterbacaan, yaitu kemudahan, kemenarikan, dan keterpahaman. Pertama, kemudahan dalam membaca berhubungan dengan bentuk tulisan, yakni tata huruf (topografi), misalnya besar kecilnya huruf dan lebar spasi. Kedua, kemenarikan dalam membaca memiliki kaitan dengan minat pembaca, kepadatan ide pada bacaan, dan keindahan gaya tulisan. Ketiga, keterpahaman berkaitan dengan karakteristik kata dan kalimat, misalnya panjang pendeknya dan frekuensi penggunaan kata atau kalimat, bangun kalimat, dan susunan paragraf dapat dipahami oleh pembaca.

Secara garis besar, keterbacaan adalah aspek yang mempersoalkan tingkat kesulitan suatu bahan bacaan tertentu bagi pembacanya. Keterbacaan menjadi salah satu tolak ukur yang menilai kesesuaian suatu bacaan dengan 
mempertimbangkan apakah bahan bacaan tersebut mudah atau sukar diterima oleh pembaca.

Tingkat keterbacaan atau readability merujuk pada seberapa mudah atau sulitnya sebuah teks dapat dibaca dan dipahami oleh target pembaca. Penelitian dalam mengukur tingkat keterbacaan bermula pada tahun 1920-an yang melibatkan dua sumber utama: ilmu mengenai kontrol kosakata dan ilmu mengenai tingkat keterbacaan (Zakaluk and Samuels). Keduanya memiliki tujuan yang sama yaitu untuk mengukur tingkat kesulitan bahan ajar. Perbedaannya terletak pada level pendidikan: ilmu mengenai kontrol kosakata ditujukan untuk level sekolah dasar, sedangkan ilmu mengenai tingkat keterbacaan ditujukan untuk level menengah, atas, universitas, dan dewasa. Standar cara pengukuran tingkat kesulitan sebuah teks dilihat dari seberapa baik hasil prediksi tingkat keterbacaan yang dicocokkan dengan skor pemahaman pembaca dengan menggunakan teks yang sama (Benjamin). Cara ini dipandang logis dan praktis untuk mengukur tingkat keterbacaan sebuah teks. Berdasarkan metodenya, terdapat lebih dari 200 macam formula yang berkembang dan digunakan untuk mengukur tingkat keterbacaan suatu teks, di antaranya Flesch Reading Ease Score, FleschKincaid Grade Level Index, Fog Index, SMOG Readability Formula, dan New Dale-Chall Readability Formula (Humphreys et al.). Berbagai macam formula tersebut tentunya digunakan sesuai dengan kebutuhan dan juga jenis teks yang akan dianalisa karena hasil pengukuran tersebut hanya merepresentasikan korelasi statistik dan mem-perkirakan tingkat kesulitan suatu teks dibandingkan menjelaskan penyebab kesulitan teks tersebut (Greenfield). Keberagaman dalam metode pengukuran keterbacaan teks menunjukkan pentingnya suatu wacana disusun dengan memperhatikan aspek-aspek yang disesuaikan dengan target pembaca dari wacana tersebut.

Dalam perkembangannya, pengukuran tingkat keterbacaan banyak diterapkan untuk meneliti berbagai jenis teks. Salah satunya adalah untuk mengukur tingkat keterbacaan buku sumber yang dipakai dalam pembelajaran di berbagai level sekolah. Dengan menggunakan Flesh-Kincaid Readibility Formula pada 8 teks berbahasa Inggris di jenjang SMP, hanya satu teks yang dianggap sesuai peruntukkannya untuk level pemahaman kelas 8, sedangkan sisanya sesuai untuk sekolah dasar (Yulianto). Ketidaksesuaian tersebut tentunya memberikan dampak pada kemampuan siswa dalam memahami konten bacaan secara komprehensif. Selain buku sumber, penelitian mengenai tingkat keterbacaan juga dilakukan untuk menganalisa jenis teks transaksional berbahasa Inggris yang diberikan untuk siswa kelas X (Sujatna). Dengan hasil total Fog Index 4.23, hal ini mengerucut pada kesimpulan bahwa teks tersebut dikategorikan sebagai teks yang mudah dibaca. Kesesuaian antara tingkat kesulitan dan target pembaca menjadi hal penting yang patut disadari oleh penulis sehingga maksud dan isi dari teks dapat tersampaikan dengan baik. Banyaknya penelitian mengenai tingkat keterbacaan di buku sumber baik bagi siswa level dasar hingga perguruan tinggi membuat penelitian ini mencoba untuk menyasar teks-teks kesehatan yang jarang disentuh oleh peneliti sebelumnya. Terlebih lagi, di masa pandemi, kebutuhan masyarakat akan informasi yang benar dan tepat mengenai kesehatan sangat diperlukan mengingat minimnya sumber informasi mengenai kesehatan yang dapat dijangkau oleh masyarakat secara merata. Oleh karena itu, penelitian mengenai tingkat keterbacaan pada teks kesehatan yang secara resmi dipublikasikan oleh WHO menjadi salah satu hal baru yang dapat mengukur kesesuaian antara tingkat kerumitan teks dengan pemahaman pembaca, dalam hal ini masyarakat umum secara global.

Dalam istilah bahasa Inggris, kerumitan tata bahasa dikenal dengan istilah Grammatical Intricacy (GI) dan kepadatan leksikal disebut Lexical Density (LD). Keduanya merujuk pada pemaparan yang menjelaskan bahwa kerumitan tata bahasa dan kepadatan leksikal menentukan jenis suatu teks kedalam dua tipe: spoken teks atau written teks (Haliday, M.A.K., Matthiessen). Mengukur tingkat keterbacaan melalui GI didefinisikan Halliday dengen membagi total jumlah tingkat klausa dengan total jumlah klausa kompleksnya seperti yang tergambar di rumus dibawah ini: 


$$
\text { GI (index) }=\frac{\text { Total number of ranking clauses }}{\text { Total number of clause complexes }}
$$

Figure1 Rumus GI (Grammatical Index)

Sedangkan untuk mengukur LD, yang digunakan sebagai tolak ukur kerumitan teks, jumlah total kata dengan sifat leksikal dibagi dengan jumlah total kata ortografi seperti rumus di bawah ini:

$L d(\%)=\frac{\text { total number of words with lexical properties }}{\text { total number of orthographic words }} \times 100$

Figure 2 Rumus LD (Lexical Density)

Setelah mendapat skor GI dan LD, untuk menentukan target pembaca teks tersebut, tabel level perkiraan target pembaca berdasarkan Fog Index milik Heydari digunakan sebagai acuan untuk menentukan kesesuaian target pembaca seperti yang tertera di tabel berikut ini:

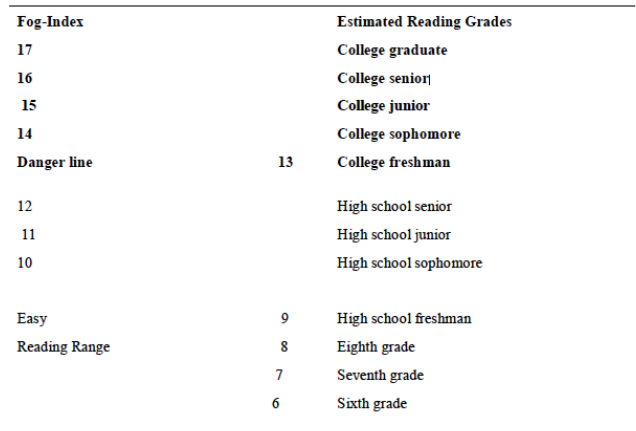

Figure 1 Fog Index dan Estimasi Target Pembaca Menurut Heydari dalam Sujatna (2019)

Memasuki revolusi industri 4.0 pada saat otomatisasi komputer mulai ditinggalkan dan peralihan ke Artificial Intelligent (AI) mulai berjalan, tantangan dunia pendidikan kedepannya adalah menyiapkan sumber daya manusia yang mampu berkolaborasi dengan teknologi dan mampu menciptakan peluang-peluang baru melalui optimalisasi teknologi. Dalam pelaksanaannya, pemanfaatan media daring dalam dunia pendidikan sudah banyak dilakukan baik oleh guru maupun siswa. Akan tetapi, dalam mengukur keterbacaan teks, keterbatasan dalam ketersediaan aplikasi masih menjadi kendala. Formula yang sejak dulu digunakan masih menggunakan media luring, sehingga konsep kolaborasi yang digaungkan oleh para pengamat tidak dapat terlaksana dengan baik. Keberadaan situs web
Using English merupakan salah satu upaya dalam memulai integrasi teknologi dalam pengembangan dunia pendidikan berbasis teknologi. Keberadaan situs web Using English yang diluncurkan pada tahun 2002 menjadi salah satu sumber rujukan dalam proses pembelajaran Bahasa Inggris yang berbentuk daring. Tidak hanya materi dalam bentuk teori yang bisa diakses oleh siswa, guru juga dapat memperoleh contoh kuis, lembar kerja, latihan soal, ataupun artikel-artikel pembelajaran.

Fitur lain yang tidak kalah menarik adalah fitur Tools and Resource. Fitur ini berisikan fitur analisis teks, penggunaan struktur, e-book yang bisa diunduh, dan pelatihan Bahasa Inggris secara daring.

Dalam laman www.usingenglish.com/resources salah satu fitur yang digunakan sebagai alat dalam penelitian ini adalah text analyser atau alat penganalisa teks. Fitur ini bekerja dengan mengkaji teks berdasarkan enam faktor: jumlah kata, kata unik, jumlah kalimat, rata-rata kata per kalimat, kepadatan leksikal, dan indeks keterbacaan Gunning Fog. Pemanfaatan situs ini dalam mengukur keterbacaan teks merupakan salah satu upaya untuk menyederhanakan proses pengukuran tingkat kerumitan suatu teks dengan bantuan teknologi. Melalui proses yang lebih mudah dan efisien, maka kedepannya diharapkan penelitian sejenis dengan menggunakan metode dan alat sejenis akan lebih berkembang.

Teks merupakan sumber data utama dalam penelitian tingkat keterbacaan dengan melihat struktur kalimat dan susunannya dalam paragraf. Dengan demikian, penelitian mengenai tingkat keterbacaan memiliki fokus pada faktor-faktor linguistik, diantaranya, jumlah kata dan jumlah kalimat. Meneliti tingkat keterbacaan suatu teks memiliki beberapa manfaat, di antaranya menentukan target level pembaca, mengklasifikasikan tingkat kesulitan suatu bahan bacaan, dan memudahkan peneliti dengan adanya berbagai macam software dalam pengukuran tingkat keterbacaan (Zamanian and Heydari). Apabila dikaitkan dengan masa pandemi Covid19, teks-teks berisikan info kesehatan menjadi tajuk utama di hampir berbagai macam media massa, tidak terkecuali di website resmi WHO. Melalui penelitian tingkat keterbacaan pada teks 
kesehatan yang dirilis di website resminya, dapat diketahui sejauh mana teks tersebut dipahami oleh target pembaca dengan adanya pengukuran kerumitan tata bahasa serta kepadatan diksinya. Dengan demikian, penelitian mengenai tingkat keterbacaan teks kesehatan di website resmi WHO perlu dilakukan atas dasar dua alasan. Pertama, penelitian ini akan mengungkap tingkat keterbacaan teks kesehatan mengenai pandemi Covid-19 yang artikelnya disusun oleh WHO. Kedua, bagi para masyarakat, penelitian ini diharapkan mampu menentukan level target pembaca sehingga penyampaian informasi menjadi tepat sasaran. Lebih jauh lagi, penelitian ini juga diharapkan mampu menjadi jembatan untuk mengukur bagaimana sebuah teks seharusnya disusun sedemikian rupa sehingga maksud dan tujuan teks dapat diterima dengan baik oleh target pembaca.

\section{METODE}

Metode yang digunakan dalam penelitian ini bersifat kualitatif dengan karakteristik bersifat deskriptif. Dalam metode ini, data yang yang dikumpulkan langsung dari sumbernya yaitu dari website resmi WHO. Peneliti memiliki andil dalam instrumen pokok analisisnya serta data yang digunakan merupakan data dalam bentuk kata-kata dalam kalimat atau gambar yang mempunyai arti (Sutopo). Subyek penelitian adalah artikel kesehatan mengenai situasi pada masa pandemi Covid-19 yang disusun dan diterbitkan oleh website resmi $W H O$ yang dapat diakses melalui www.who.int. Empat artikel terpilih yang dianalisis mencakup latar belakang penyebaran virus, langkah pencegahan, penjelasan gejala, sarana informasi terkait perlindungan diri, dan seputar mitos mengenai virus yang berkembang di masyarakat. Pemilihan keempat teks tersebut didasarkan pada penempatan artikel yang menjadi tajuk utama di bagian Diseases mengenai pandemi Covid19. Keempat artikel tersebut adalah:
1. Coronavirus disease (Covid-19) advice for the public: When and how to use masks

2. Coronavirus disease (Covid-19): Small public gatherings

3. Covid-19 advice for the public: Getting vaccinated

4. Why do the virus and the disease have different names?

Teknik pengumpulan data dalam penelitian ini dilakukan melalui studi dokumenter dan analisis. Teks yang dikumpulkan kemudian diolah menjadi data yang berasal hasil komputasi text analyser pada situs Using English.com berupa tingkat keterbacaan teksteks reading pada artikel kesehatan mengenai pandemi Covid-19 di website resmi WHO. Adapun langkah-langkah analisis teks dengan menggunakan text analyser yaitu:

1. Membuka laman www.usingenglish.com

2. Pilih menu 'Resources' lalu pilih 'Text Analyser'

3. Ketik/salin teks yang akan dianalisa kedalam kotak kosong yang tersedia, lalu ketik 'Calculate Now'.

4. Hasil statistik teks kemudian akan muncul dalam bentuk angka.

5. Menjabarkan dan menginterpretasi hasil tingkat keterbacaan

Dalam menafsirkan data, proses analisis ini mengggunakan teori Gramma-tical Intricacy (GI) dan Lexical Density (LD) oleh Halliday yang menitikberatkan pada kerumitan tata bahasa serta kepadatan diksi melalui pemanfaatan text analyzer website www.usingenglish.com dalam pengukuran tingkat keterbacaan teks kesehatan tersebut. Secara sederhana, teks-teks berupa rangkaian kalimat yang diambil dari website kemudian dimasukkan kedalam text analyzer yang kemudian akan muncul jumlah GI dan LD dalam bentuk angka dan persentase. 
Hasil tersebut kemudian diinterpretasikan sesuai dengan kategorisasi teks di level mudah, sedang, atau sulit sesuai dengan tingkat keterbacaannya.

\section{HASIL PENELITIAN}

Hasil analisis terhadap empat artikel kesehatan mengenai pandemi COVID-19 yang dipublikasikan di website resmi WHO melalui text analyzer menunjukkan lima aspek penilaian, yaitu: jumlah total kata (total word count), jumlah total kata unik (total unique words), jumlah kalimat, rata-rata panjang kalimat, dan jumlah paragraf. Setelah data teridentifikasi melalui lima komponen diatas, maka seluruh data dianalisa kembali melalui tiga komponen penilaian untuk mengukur tingkat keterbacaan artikel tersebut yang mencakup: presentase kata-kata sulit hard words, presentase Lexical Density (LD), dan presentase Fox Index. Dalam menentukan tingkat keterbacaan, maka tabel perkiraan level pembaca dan Fog Index Heydari diperlukan sebagai acuan. Dari empat teks yang dianalisa, setiap teks diberi identitas T1, T2, T3 dan T4 untuk membedakan antara satu dengan yang lain.

Berikut merupakan hasil dari empat teks yang telah dianalisis dengan tampilan dalam kategori readibility, summary, dan word length breakdown secara berurutan:

\begin{tabular}{ll} 
Readability & \\
\hline Hard Words (?): & $19(9.22 \%)$ \\
\hline Long Words (?): & $34(16.50 \%)$ \\
\hline Lexical Density (?): & 60.19
\end{tabular}

Gunning Fog: 11.7 (text scale) Gunning Fog scored your text: hard to read. [f] I [a] $\mid[\underline{r}]$

\begin{tabular}{ll} 
Readability & \\
\hline Hard Words (?): & $52(15.29 \%)$ \\
\hline Long Words (?): & $98(28.82 \%)$ \\
\hline Lexical Density (?): & 56.76
\end{tabular}

Gunning Fog: 10 (text scale)

Gunning Fog scored your text: fairly easy to read. [f] l [ [a] $]$ [ [r]

Figure 2 Tingkat Keterbacaan T1 dan T2

\begin{tabular}{ll} 
Readability & \\
\hline Hard Words (?): & $135(16.54 \%)$ \\
\hline Long Words (?): & $252(30.88 \%)$ \\
\hline Lexical Density (?): & 45.59
\end{tabular}

Gunning Fog: 15.6 (text scale)

Gunning Fog scored your text: difficult to read. [f] I [a] $\mid[\underline{r}]$

\begin{tabular}{ll} 
Readability & \\
\hline Hard Words (?): & $64(25.00 \%)$ \\
\hline Long Words (?): & $86(33.59 \%)$ \\
\hline Lexical Density (?): & 47.66
\end{tabular}

Gunning Fog: 12.9 (text scale)

Gunning Fog scored your text: hard to read. [f] I [a ] I [ r ]

Figure 3 Tingkat Keterbacaan T3 dan T4

\begin{tabular}{ll} 
Summary & \\
\hline Total Word Count: & 206 \\
\hline Word Count (Excluding Common Words): & 108 \\
\hline Number of Different Words: & 124 \\
\hline Different Words (Excluding Common Words): & 84 \\
\hline Number of Paragraphs: & 8 \\
\hline Number of Sentences: & 4 \\
\hline Words per Sentence: & 51.5 \\
\hline Number of Characters (all): & 1,115 \\
\hline Number of Characters (a-z): & 872 \\
\hline Characters per Word: & 4.2 \\
\hline Syllables: & 289 \\
\hline Syllables per Word: & 1.4
\end{tabular}




\section{Text Statistics}

\begin{tabular}{|ll|}
\hline Summary & \\
\hline Total Word Count: & 340 \\
\hline Word Count (Excluding Common Words): & 199 \\
\hline Number of Different Words: & 193 \\
\hline Different Words (Excluding Common Words): & 148 \\
\hline Number of Paragraphs: & 14 \\
\hline Number of Sentences: & 9 \\
\hline Words per Sentence: & 37.8 \\
\hline Number of Characters (all): & 2,178 \\
\hline Number of Characters (a-z): & 1,754 \\
\hline Characters per Word: & 5.2 \\
\hline Syllables: & 577 \\
\hline Syllables per Word: & 1.7 \\
\hline
\end{tabular}

Figure 4 Statistik Teks T1 dan T2

\section{Text Statistics}

\begin{tabular}{ll}
\hline Summary & \\
\hline Total Word Count: & 816 \\
\hline Word Count (Excluding Common Words): & 454 \\
\hline Number of Different Words: & 372 \\
\hline Different Words (Excluding Common Words): & 302 \\
\hline Number of Paragraphs: & 43 \\
\hline Number of Sentences: & 18 \\
\hline Words per Sentence: & 45.3 \\
\hline Number of Characters (all): & 5,157 \\
\hline Number of Characters (a-z): & 4,114 \\
\hline Characters per Word: & 5.0 \\
\hline Syllables: & 1,359 \\
\hline Syllables per Word: & 1.7 \\
\hline
\end{tabular}

\section{Text Statistics}

\section{Summary}

Total Word Count:

Word Count (Excluding Common Words):

154

Number of Different Words:

Different Words (Excluding Common Words): $\quad 92$

Number of Paragraphs:

Number of Sentences:

14

Words per Sentence:

Number of Characters (all):

32.0

1,736

Number of Characters (a-z):

1,371

Characters per Word:

5.4

Syllables:

470

Syllables per Word:
Figure 5 Statistik Teks T3 dan T4

\begin{tabular}{lll}
\hline Length & Count & Percentage of all words \\
\hline 1 letter words & 12 & $5.8 \%$ \\
\hline 2 letter words & 39 & $18.9 \%$ \\
\hline 3 letter words & 29 & $14.1 \%$ \\
\hline 4 letter words & 38 & $18.4 \%$ \\
\hline 5 letter words & 24 & $11.7 \%$ \\
\hline 6 letter words & 16 & $7.8 \%$ \\
\hline 7 letter words & 10 & $4.9 \%$ \\
\hline 8 letter words & 11 & $5.3 \%$ \\
\hline 9 letter words & 6 & $2.9 \%$ \\
\hline 10 letter words & 6 & $2.9 \%$ \\
\hline 11 letter words & 2 & $1.0 \%$ \\
\hline 12 letter words & 2 & $1.0 \%$ \\
\hline 13 letter words & 1 & $0.5 \%$ \\
\hline
\end{tabular}

\begin{tabular}{lll}
\hline Length & Count & Percentage of all words \\
\hline 1 letter words & 20 & $5.9 \%$ \\
\hline 2 letter words & 56 & $16.5 \%$ \\
\hline 3 letter words & 35 & $10.3 \%$ \\
\hline 4 letter words & 40 & $11.8 \%$ \\
\hline 5 letter words & 37 & $10.9 \%$ \\
\hline 6 letter words & 39 & $11.5 \%$ \\
\hline 7 letter words & 22 & $6.5 \%$ \\
\hline 8 letter words & 22 & $6.5 \%$ \\
\hline 9 letter words & 13 & $3.8 \%$ \\
\hline 10 letter words & 20 & $5.9 \%$ \\
\hline 11 letter words & 12 & $3.5 \%$ \\
\hline 12 letter words & 4 & $1.2 \%$ \\
\hline 13 letter words & 3 & $0.9 \%$ \\
\hline 14 letter words & 2 & $0.6 \%$ \\
\hline 16 letter words & 2 & $0.6 \%$ \\
\hline 23 letter words & 1 & $0.3 \%$ \\
\hline
\end{tabular}

Figure 6 Panjang Kata T1 dan T2 


\begin{tabular}{|c|c|c|}
\hline Length & Count & Percentage of all words \\
\hline 1 letter words & 20 & $2.5 \%$ \\
\hline 2 letter words & 128 & $15.7 \%$ \\
\hline 3 letter words & 134 & $16.4 \%$ \\
\hline 4 letter words & 113 & $13.8 \%$ \\
\hline 5 letter words & 70 & $8.6 \%$ \\
\hline 6 letter words & 58 & $7.1 \%$ \\
\hline 7 letter words & 67 & $8.2 \%$ \\
\hline 8 letter words & 82 & $10.0 \%$ \\
\hline 9 letter words & 29 & $3.6 \%$ \\
\hline 10 letter words & 27 & $3.3 \%$ \\
\hline 11 letter words & 19 & $2.3 \%$ \\
\hline 12 letter words & 10 & $1.2 \%$ \\
\hline 13 letter words & 7 & $0.9 \%$ \\
\hline 14 letter words & 4 & $0.5 \%$ \\
\hline 15 letter words & 4 & $0.5 \%$ \\
\hline 16 letter words & 1 & $0.1 \%$ \\
\hline 25 letter words & 1 & $0.1 \%$ \\
\hline 29 letter words & 1 & $0.1 \%$ \\
\hline 48 letter words & 1 & $0.1 \%$ \\
\hline
\end{tabular}

\begin{tabular}{lll}
\hline Length & Count & Percentage of all words \\
\hline 1 letter words & 3 & $1.2 \%$ \\
\hline 2 letter words & 33 & $12.9 \%$ \\
\hline 3 letter words & 59 & $23.0 \%$ \\
\hline 4 letter words & 23 & $9.0 \%$ \\
\hline 5 letter words & 29 & $11.3 \%$ \\
\hline 6 letter words & 13 & $5.1 \%$ \\
\hline 7 letter words & 20 & $7.8 \%$ \\
\hline 8 letter words & 18 & $7.0 \%$ \\
\hline 9 letter words & 15 & $5.9 \%$ \\
\hline 10 letter words & 12 & $4.7 \%$ \\
\hline 11 letter words & 13 & $5.1 \%$ \\
\hline 12 letter words & 3 & $1.2 \%$ \\
\hline 13 letter words & 3 & $1.2 \%$ \\
\hline 14 letter words & 1 & $0.4 \%$ \\
\hline 15 letter words & 1 & $0.4 \%$ \\
\hline 16 letter words & 1 & $0.4 \%$ \\
\hline
\end{tabular}

Figure 7 Panjang Kata T3 dan T4

\section{Pembahasan}

Keterbacaan teks T1-T4 dimulai dengan pembahasan word length breakdown atau panjang kata dari masing-masing teks. Setiap teks memiliki 1 kata sebagai kata terpendek dan 48 kata sebagai kata terpanjang. Secara rinci, perbandingan jumlah kata di masing-masing teks T1 hingga T4 digambarkan dalam tabel berikut ini:

\section{Table 1 Word Length Breakdown di T1-T4}

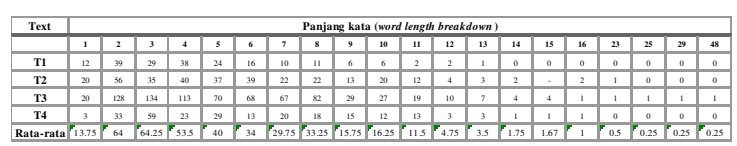

Tabel 1 menunjukkan data mengenai ratarata jumlah kata di empat teks kesehatan. Angka tertinggi jumlah rata-rata kata adalah 64,25 kata yang memiliki 3 suku kata dan yang terendah adalah yang memiliki 25, 29, dan 48 suku kata. Pembahasan selanjutnya adalah mengenai jumlah total kata yang ditampilkan dalam tabel berikut ini:

Table 2 Total Word Count (Jumlah Kata) di T1-T4

\begin{tabular}{|c|c|c|c|c|}
\hline 1 & 2 & 3 & 4 & Dotonets \\
\hline T1 & T2 & T3 & $\mathrm{T4}$ & Rata-rata \\
\hline 206 & 340 & 816 & 256 & 405 \\
\hline
\end{tabular}

Dari tabel di atas, teks yang memiliki jumlah kata terbanyak adalah T3 dengan 816 kata dan teks dengan jumlah kata terendah adalah T1 dengan 206 kata. Sebagai rata-rata, keempat teks memiliki jumlah rata-rata 405 kata.

Selanjutnya, different words (kata unik) pada masing-masing teks tergambar di tabel berikut ini:

Table 3 Different Words (Kata Unik) di T1-T4

\begin{tabular}{|c|c|c|c|c|}
\hline 1 & 2 & 3 & 4 & Rata-rata \\
\hline T1 & T2 & T3 & T4 & Kata-rata \\
\hline 84 & 148 & 302 & 92 & 157 \\
\hline
\end{tabular}

Kata unik menunjukkan penggunaan kata yang berbeda di setiap penulisannya. Berdasarkan tabel di atas, teks yang memiliki kata unik terbanyak adalah T3 dengan jumlah kata 302 dan yang terendah adalah T1 dengan jumlah kata 84 . Kata unik menandakan bahwa teks menghindari kecenderungan untuk mengulang kata yang sama (repeated words) dan 
102 Alinea: Jurnal Bahasa, Sastra, dan Pengajaran Volume 10, (2) Oktober 2021, hal. 94-105

memilih untuk menggunakan kata lain yang memiliki makna yang sama. Hal ini juga menunjukkan bahwa penggunaan variasi kata di T3 cenderung lebih tinggi disbanding teks lain.

Pembahasan selanjutnya adalah jumlah kalimat dan jumlah paragraph di T1 hingga T4 yang diilustrasikan pada tabel dibawah ini:

Table 4 Jumlah Kalimat dan Paragraf di T1T4

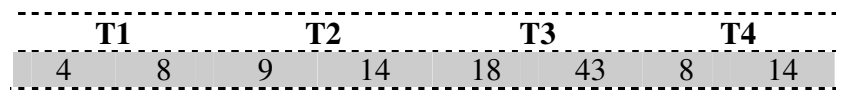

Jumlah kalimat dan paragraph bervariasi di masing-masing teks. T3 menempati posisi tertinggi untuk jumlah kalimat dan paragraph dengan nilai 18 kalimat dan 43 paragraf, sedangkan yang terendah ditempati oleh T1 dengan 4 kalimat dan 8 paragraf. Jumlah kalimat yang lebih rendah dari paragraf menunjukkan bahwa ide pokok suatu kalimat bisa sangat panjang dan kompleks, sehingga membutuhkan pemahaman pembaca yang sangat baik agar maksud teks dapat tersampaikan dengan tepat.

Dari hasil tingkat keterbacaan T1 hingga $\mathrm{T} 4$, fokus selanjutnya adalah presentase katakata sulit (hard words) yang muncul di masing-masing teks. Hard words merujuk pada kata yang memiliki tiga suku kata atau lebih yang ditampilkan dalam tabel dibawah ini:

Table 5 Hard Words di Teks T1-T4 (dalam presentase)

\begin{tabular}{ccc} 
T1 & T3 & T4 Rata-rata \\
\hline 9,22 & 15,29 & 16,54 \\
\hline
\end{tabular}

Tabel 5 menunjukkan bahwa teks T4 memiliki hard words yang lebih tinggi dengan nilai $25 \%$ dibandingkan dengan teks lainnya. T1 memiliki hard words terendah dengan nilai hanya $9,22 \%$. Rata-rata jumlah hard words di keempat teks adalah $16,51 \%$.
Bahsan selanjutnya adalah presentase Lexical Density (LD) pada T1 hingga T4. Seperti yang telah dipaparkan sebelumnya, LD merujuk pada kerapatan leksikal yang dipengaruhi oleh unique words dan jumlah kata (total kata yang terhitung dalam text statistics). LD merupakan gambaran bagaimana sebuah teks dapat dibaca sebagai teks yang mudah (easy) atau sulit (difficult) dipahami oleh target pembacanya. Hal ini menunjukkan bahwa semakin beragamnya penggunan kata leksikal di sebuah teks akan memberikan presentase LD yang tinggi dan berlaku sebaliknya. Di sisi lain, LD memiliki kaitan yang sangat erat dengan Grammatical Intricacy (GI). Teks yang memiliki LD tinggi cenderung memiliki GI yang rendah, dan teks yang memiliki LD rendah cenderung memiliki GI yang tinggi. Berikut adalah tabel yang menunjukkan presentase LD dari T1 hingga T4:

Table 6 Lexical Density di Teks T1-T4 (dalam persentase)

\begin{tabular}{|c|c|c|c|c|}
\hline T1 & $\mathrm{T} 2$ & T3 & $\mathrm{T} 4$ & Rata-rata \\
\hline 60,19 & 56,76 & 45,59 & 47,66 & $\mathbf{5 2 , 5 5}$ \\
\hline
\end{tabular}

Tabel 6 menunjukkan bahwa teks T1 memiliki presentase LD tertinggi dengan nilai $60,19 \%$ dan teks T3 memiliki presentase terendah dengan nilai $56,57 \%$. Rata-rata LD dari keempat teks adalah 52,55\%. Dengan nilai tersebut, keempat teks kesehatan dalam penelitian ini dapat diklasifikasikan kedalam written teks. Artinya, teks tersebut membutuhkan pemahaman target pembaca dalam mengerti konteks, mencari referensi, mengisi gaps yang tidak dipahami sebelumnya, dan menyatukan serta mengkonsolidasikan faktorfaktor tersebut aar dapat memahami teks secara koheren.

Fokus terakhir adalah Fog Index. Sama halnya dengan LD, Fog Index juga menentukan bagaimana sebuah teks dapat dipahami oleh target pembacanya. Berikut adalah tabel 
yang menunjukkan presentase Fog Index dari T1 hingga T4:

\section{Table 7 Fog Index di Teks T1-T4}

T1 T2 T3 T4 Rata-rata

Tabel 7 menunjukkan bahwa teks dengan Fog Index tertinggi adalah T3 dengan nilai 15,6 dan yang terendah adalah T2 dengan presentase 10. Rata-rata nilai Fog Index dari keempat teks adalah 12,55. Dibandingkan dengan temuan di penelitian sebelumnya yang banyak mengangkat isu mengenai tingkat keterbacaan di buku teks ataupun buku cerita anak-anak, angka yang dihasilkan rata-rata berbeda dengan teks yang mengangkat isu kesehatan. Buku teks pelajaran berbahasa Inggris ataupun buku cerita anak-anak mayoritas berada di index 6-9 dengan level mudah, sedangkan teks kesehatan yang diangkat dalam penelitian ini berada di level sulit dengan index diatas 12 .

Dengan mengacu pada tabel Heydari dalam Sujatna (2019) mengenai hubungan Fog Index dengan perkiraan lezqvel pembaca (Estimated Reading Grades), dapat disimpulkan bahwa keempat teks kesehatan ini merupakan teks dengan tingkat kesulitan cukup tinggi dan ditujukan bagi pembaca untuk level sekolah menengah atas hingga perguruan tinggi (high school to college freshmen).

Berdasarkan data ini, keempat teks yang dipublikasikan tersebut tidak sesuai dengan target pembacanya yang mayoritas masyarakat umum. Agar teks tersebut dapat dibaca oleh masyarakat umum, penyusunan teks berisikan informasi kesehatan ada baiknya menggandeng ahli bahasa sebagai editor untuk memastikan tingkat keterbacaannya sesuai dengan target pembaca.

Merujuk pada penelitian sebelumnya yang sama-sama mengidentifikasi tingkat keterbacaan suatu teks, penelitian ini memiliki kontribusi bagi $W H O$ sebagai institusi yang menyusun dan menyajikan data serta informasi mengenai pandemi kepaada masyarakat luas agar kedepannya turut mempertimbangkan bagaimana target pembaca yang menjadi sasaran utama dipublikasikannya artikel kesehatan tersebut. Dengan menyesuaikan penggunaan kata dan bahasa sesuai target pembacanya, informasi dan data mengenai penanganan Covid-19 bagi masyarakat awam dapat dipahami dengan baik.

\section{SIMPULAN}

Mengukur tingkat keterbacaan teks bertujuan untuk memastikan apakah teks yang disusun sedemikian rupa oleh penulis dapat dipahami dengan baik oleh target pembacanya. Sebagai badan resmi kesehatan dunia, WHO memiliki peranan penting dalam menyampaikan informasi kesehatan yang bermanfaat bagi masyarakat.

Dari empat teks yang dianalisis, dapat dilihat bahwa tingkat keterbacaaan teks kesehatan yang dipublikasikan oleh $W H O$, khususnya mengenai pandemi Covid-19, dikategorikan sebagai teks dengan tingkat kesulitan tinggi dengan nilai Fog Index untuk T1 hingga $\mathrm{T} 4$ secara berurutan sebagai berikut: T1 $(11,7), \mathrm{T} 2(10), \mathrm{T} 3(15,6)$, dan T4 $(12,9)$. Hal ini turut ditandai dengan tingginya rata-rata nilai LD (Lexical Density) yaitu 52,55\% yang mengerucut pada kesimpulan bahwa teks tersebut membutuhkan pemahaman yang cukup mendalam bagi target pembaca agar isi dan makna teks dapat dicerna dengan baik.

Sebagai tambahan, nilai Fog Index dari keempat teks yang dianalisa dalam penelitian menunjukkan nilai rata-rata 12,55 yang mencirikan bahwa teks tersebut diperuntukkan untuk pembaca yang diasumsikan telah memperoleh pendidikan minimal sekolah menengah ke atas hingga perguruan tinggi. Artinya, teks kesehatan mengenai pandemi 
Covid-19 yang dipublikasikan oleh $W H O$ di website resminya tidak bisa serta merta dipahami oleh seluruh kalangan masyarakat dikarenakan jenis teksnya yang dikategorikan sebagai teks dengan kesulitan tinggi (hard texts). Sebagai rekomendasi, penyusunan sebuah teks kesehatan berisikan informasi yang mentargetkan masyarakat umum sebagai pembacanya sebaiknya turut menggandeng ahli bahasa sebagai editor tata bahasa. Hal ini dimaksudkan agar teks yang dipublikasikan dapat dicek tingkat keterbacaannya sehingga informasi yang ingin disampaikan dapat diterima dengan baik oleh target pembaca.

\section{DAFTAR PUSTAKA}

Anjarkusuma, Dewangga, et al. "Penggunaan Aplikasi CMS Wordpress untuk Merancang Website Sebagai Media Promosi pada Maroon Wedding Malang." Jurnal Akuntansi, Ekonomi, dan Manajemen Bisnis, vol. 2, no. 1, 2014, p. 63, http://herrypernando.blogspot.com.

Apriananta, Yosua Jefri, and Lina Sinatra Wijaya. "Penggunaan Website dan Media Sosial dalam Membangun Citra Positif Perguruan Tinggi." Jurnal Komunikatif, vol. 7, no. 2, 2018, pp. 187-209, doi:10.33508/jk.v7i2.1750.

Benjamin, Rebekah George. "Reconstructing Readability: Recent Developments and Recommendations in the Analysis of Text Difficulty." Educational Psychology Review, vol. 24, no. 1, 2012, pp. 63-88, doi:10.1007/s10648-011-9181-8.

DuBay, William H. "The Principles of Readability: A Brief Introduction to Readability Research.” Impact Information, no. 949, 2004, pp. 1-72, http://scholar.google.com/scholar?hl=en\&btnG=Search\&q=intitle:The+Principles+of+Read ability\#1.

Greenfield, Jerry. "Readability Formulas For EFL.” JALT Journal, vol. 26, no. 1, 2004, p. 5, doi:10.37546/jaltjj26.1-1.

Haliday, M.A.K., Matthiessen, C. M. I. M. An Introduction to Functional Grammar. Third, Hodder Arnold, 2014.

Hidayat, Taufik. "Trend Teknologi Revolusi Industri 4.0.” Direktorat Sistem Informasi Dan Teknologi UNIDA, 2019, https://www.unida.ac.id/teknologi/artikel/trend-teknologirevolusi-industri-40.html\#: :text=Revolusi Industri 4.0 merupakan sebuah,model bisnis baru berbasis digital.

Humphreys, Alexandra H., et al. "Reading Difficulty Levels of Selected Articles in the Journal of Research in Music Education and Journal of Historical Research in Music Education." Music Education Research International, vol. 6, 2013, pp. 15-25.

Muharam, Masyhar, and Andhika Giri Persada. "Implementasi Penggunaan Website Sebagai Media Informasi dan Media Pemasaran Hasil Pertanian dan Peternakan Desa Sumberejo." Automata, vol. 1, no. 2, 2020, www.desasumberejo.com.

Suherli. Keterbacaan Buku Teks Pelajaran. 2008, http://suherlicentre.blogspot.com/2008/07/keterbacaan-buku-teks-pelajaran.html. 
Sujatna, Eva Tuckyta Sari. "Readability of the Transactional Texts in Bahasa Inggris Textbook for Grade X." International Journal of Systemic Functional Linguistics, vol. 2, no. 1, 2019, pp. 33-42, https://ejournal.warmadewa.ac.id/index.php/ijsfl.

Sutopo, HB. Metode Penelitian Kualitatif. UNS Press, 2006.

Yulianto. "An Analysis on Readability Level of English Reading Texts for Eighth Grade Students.” Journal of English for Academic, vol. 6, no. 1, 2019, pp. 81-91.

Zakaluk, Beverley L., and S. Jay Samuels. Readibility: Its Past, Present, and Future. 1988.

Zamanian, Mostafa, and Pooneh Heydari. "Readability of Texts: State of the Art." Theory and Practice in Language Studies, vol. 2, no. 1, 2012, pp. 43-53, doi:10.4304/tpls.2.1.43-53. 